J. Perinat. Med.

9 (1981) 87

\title{
Mecillinam (Selexidin) in the treatment of neonates
}

\author{
J. de Louvois, A. Mulhall, R. Hurley
}

Queen Charlotte's Hospital for Women and the Institute of Obstetrics, Goldhawk Road, London

\section{Introduction}

The diagnosis of neonatal septicaemia must be considered in almost every sick newborn infant [4], but definitive aetiological diagnosis and management, particularly treatment with antibac. terial antibiotics, poses problems. While the combination of penicillin and an aminoglycoside should meet most bacterial eventualities [2], the presumptive diagnosis of septicaemia or other serious microbial disease is unconfirmed in most of the babies to whom the drugs have been given, and there is no doubt that a safe, effective altemative to the aminoglycosides is required. Because of the emergence of resistance in microbes previously deemed sensitive, ampicillin is no longer so useful as it once was. It is important that the first choice antibiotics should not be toxic, and that aminoglycosides be reserved for life threatening situations and for cases in which there is a high probability of infection with organisms resistant to other antimicrobial agents.

The amidinopenicillin, mecillinam (Selexidin, LEO LABORATORIES), first described by LUND and TYBRING [7], has an antibacterial spectrum confined to the enteric Gram-negative aerobic rods [12] and is bactericidal to a high percentage of ampicillin resistant strains of Escherichia coli [9]. Its toxicity is no greater than that of the penicillins and it does not exert teratogenic effects [3]. Synergy between mecillinam and other $\beta$ lactam drugs has been demonstrated in vitro $[6$, $10,13]$ and in vivo $[5]$.
Curriculum vitae

JOHN DE LOUVOIS principal microbiologist at Queen Charlotte's Maternity Hospital, London was borm in 1937. He was awarded an M. Sc. degree in 1973 and $a P h . D$. in the faculty of Medicine, University of London in 1977. His microbiological areas of interest are obstetrics, neonatalogy and chemotherapy on which subjects he has published a number of scientific papers.

In this preliminary study, we evaluate aspects of the pharmacokinetics of mecillinam, used in combination with penicillin, in the treatment of seventy neonates in a Special Care Baby Unit. Particular regard has been paid to the safety of the agent.

\section{Subjects}

Thirty-four male and thirty-six female babies, with a mean gestational age of $34.5 \pm 4.9$ weeks and mean birthweight of $2.2 \pm 0.9 \mathrm{~kg}$ were treated by intramuscular injection of mecillinam and penicillin. The mode of delivery included spontaneous vertex vaginal delivery, 24 , breech delivery, 6 , forceps delivery, 15, elective lower segment caesarean section, 15, and emergency lower seg- 
ment caesarean section, 6 ; the mode of delivery was not recorded in four babies transferred from other units. Fifty-four babies were preterm; thirteen of them being less than thirty weeks gestation and forty-five had a birthweight of less than 2.5 $\mathrm{kg}$. In all cases birth and early neonatal life were accompanied by complications, often multiple, known to predispose to potentially lethal infections, or to presage them [4]. They included prolonged rupture of membranes, 26 , birth asphyxia, 12, maternal pyrexia, 9, neonatal pyrexia, 4, meconium aspiration, 10, respiratory distress or hyaline membrane disease, 18, pneumothorax, 5 , or fetal tachycardia, 4 .

Previous to this study, all the babies would have received either ampicillin and flucloxacillin or a penicillin and gentamicin, depending on the gravity of the clinical state.

\subsection{Treatment regimen}

The dosage regimen was mecillinam* $(40 \mathrm{mg} / \mathrm{kg} /$ day) and penicillin (60000 units/kg/day) separately administered in divided doses by intramuscular injection at six hourly intervals for five days. In eleven patients treatment was not completed and for two patients further courses were prescribed.

\subsection{Laboratory investigations}

The incidence of mecillinam resistant organisms isolated from patients within the Special Care Baby Unit was determined before the introduction of mecillinam and during the first six months of use. Surface swabs and blood cultures were collected prior to treatment. Capillary samples of blood were collected for estimation of serum urea, total protein, albumin and alanine aminotransferase (ALAT) before mecillinam therapy was begun, during the third or fourth day of treatment and two days after the course of treatment had been completed. The results of other biochemical, haematological and microbiological investigations requested by paediatricians on the patients were also analysed.

\footnotetext{
* Selexidin (kindly supplied by LEO LABORATORIES Ltd.).
}

\subsection{Mecillinam assay}

One hundred and twenty-one samples of blood from 59 babies were collected for assay of mecillinam at timed intervals by heel prick or via an arterial line. The assay was performed by a plate diffusion technique using Enterobacter species (LEO LABORATORIES HC12) as test organism and an assay medium consisting of $0.5 \%$ yeast extract (Difco) in $1 \%$ agar. The indicator organism was sensitive to mecillinam (MIC $0.5 \mathrm{mg} / \mathrm{l}$ ), resistant to penicillin and did not exhibit synergy. Assays were set up within two hours of collection using horse serum standards prepared while the clinical samples were being collected.

\subsection{Sensitivity testing}

Sensitivity of Gram-negative rods to mecillinam was determined on Diagnostic Sensitivity Test (DST) medium (Oxoid) using a $10 \mathrm{mcg}$ disc. Initially E. coli (NCTC 10418) was used as a control. Later results were read from a regression line available from Leo Laboratories. The minimal inhibitory concentration of mecillinam was determined by the method of NEU [10] for all organisms appearing less sensitive than the control.

\section{Results}

Bacteriological investigations were undertaken in sixty-six babies, before treatment with mecillinam

Tab. I. Bacteriological investigations on 66 babies before therapy with mecillinam

\begin{tabular}{|c|c|c|}
\hline Type of Specimen & $\begin{array}{l}\text { Number of } \\
\text { Specimens }\end{array}$ & $\begin{array}{l}\text { Those yielding } \\
\text { pathogens or poten- } \\
\text { tial pathogens } \\
\text { (19 babies) }\end{array}$ \\
\hline $\begin{array}{l}\text { Swabs from } \\
\text { superficial sites }\end{array}$ & 172 & 23 \\
\hline Faeces or rectal swabs & 28 & 1 \\
\hline Blood cultures & 55 & 9 \\
\hline Cerebrospinal fluid & 6 & 0 \\
\hline Urine & 19 & 2 \\
\hline IV Catheter tips & 9 & 1 \\
\hline \multirow{2}{*}{$\begin{array}{l}\text { Tracheal or gastric } \\
\text { aspirates }\end{array}$} & 9 & 1 \\
\hline & 298 & 37 \\
\hline
\end{tabular}


was commenced. Two hundred and ninety-eight specimens were examined. Pathogens or potential pathogens were cultured from nineteen babies (29\%) in thirty-seven instances (Tab. I), and details of the bacteria isolated are shown in Tab. II.

More than one pathogen was cultured from six babies. Gram-negative rods sensitive to mecillinam were isolated from seven babies in fifteen instances. None of the babies had meningitis but blood culture was positive in nine babies (14\%) (Tab. III). Details of those in whom infection was confirmed, or who were deemed at high risk of serious infection supervening because pathogenic bacteria had been isolated from parental tubes, infected cord site or from multiple superficial sites are given in Tab. III.
The sensitivity of appropriate microbes to mecillinam was established over a period of four months before the introduction of mecillinam, and during and after the trial, over an eight month period. Approximately three hundred isolates of enteric, aerobic Gram-negative rods were tested, and there was no rise in the numbers of mecillinam resistant organisms isolated. The sensitivity of microbes to the drug did not alter during treatment.

Fifty-nine babies received the full five day course of mecillinam with penicillin; in two of them, it was prolonged to ten and nineteen days respectively. Eleven other babies received less than the five day course: In six, with either proven systemic infection, 3 , or deteriorating clinical state, 3 , two of whom died subsequently, mecillinam was replaced by gentamicin for ethical reasons; in two, it

Tab. II. Pathogenic or potentially pathogenic bacteria isolated from $19 / 66$ infants

\begin{tabular}{|c|c|c|c|c|c|}
\hline Organism & $\begin{array}{l}\text { Number } \\
\text { of babies }\end{array}$ & $\begin{array}{l}\text { Blood } \\
\text { culture (9) }\end{array}$ & $\begin{array}{l}\text { Urine } \\
(2)\end{array}$ & $\begin{array}{l}\text { Aspirates and } \\
\text { Catheter Tips } \\
\text { (2) }\end{array}$ & $\begin{array}{l}\text { Superficial } \\
\text { sites }(23)\end{array}$ \\
\hline Staphylococcus aureus & 3 & - & - & 1 & 3 \\
\hline Staphylococcus epidermidis & $1 *$ & $1 *$ & 1 & - & - \\
\hline Streptococcus agalactiae & 3 & 1 (1) & - & - & 7 (7) \\
\hline Other streptococci & $2 *$ & $1 *(1)$ & - & - & $2 *(2)$ \\
\hline Escherichia coli & $3 *$ & 1 (1) & $1(1)$ & - & $5 *(5)$ \\
\hline Klebsiella aerogenes & 1 & 1 (1) & - & - & - \\
\hline Proteus species & 2 & - & - & $1(1)$ & 4 (3) \\
\hline Pseudomonas aeruginosa & 1 & 1 & - & - & - \\
\hline Other Gram-negative rods & 4 & 4 (2) & - & - & - \\
\hline Neisseria gonorrhoeae & 1 & - & - & - & $4(4)$ \\
\hline
\end{tabular}

* indicates a mixed culture

The figures in brackets are mecillinam or penicillin sensitive isolates.

Tab. III. Bacteriologically confirmed diagnosis in 16 of 66 babies

\begin{tabular}{lll}
\hline Diagnosis & $\begin{array}{l}\text { Number of } \\
\text { babies }\end{array}$ & Associated Microbes \\
\hline $\begin{array}{l}\text { Septicaemia } \\
\begin{array}{l}\text { Urinary tract } \\
\text { infection }\end{array}\end{array}$ & 2 & See Table 2 \\
$\begin{array}{l}\text { Grave risk of } \\
\text { septicaemia or } \\
\text { other infection } \\
\text { supervening }\end{array}$ & 5 & See Table 2 \\
\hline
\end{tabular}

was discontinued on discharge or on transfer for surgery; two died of non-bacterial disease (hyaline membrane disease; disseminated herpes) during treatment, and all treatment was withheld from a baby with Down's syndrome.

The overall mortality in the fully and partially treated babies was 11.4 per cent $(8 / 70)$. Four deaths occurred in the 59 babies in whom therapy with mecillinam was completed: One baby died of bronchopulmonary dysplasia, one died following surgery and two died 4 months after being discharged from hospital. One of these was ad- 
mitted to another hospital and died of septicaemia. This baby had been treated successfully with mecillinam for Escherichia coli septicaemia, and succumbed, four months later, to an unrelated further episode of septicaemia, diagnosed at post mortem examination as probably meningococcal in origin. Four of the eleven in whom mecillinam was discontinued also died, of disseminated herpes, of hyaline membrane disease, of massive pulmonary haemorrhage and of intraventricular haemorrhage, the latter following hyaline membrane disease and bronchopulmonary dysplasia, respectively. Thus only one of the eight deaths was associated with infection.

Biochemical tests were performed on sixty-six babies (Tab. IV). Summating the observations in the three groups tested, the majority of results fell within the normal range for ALAT (93\%) total protein (79\%) and albumin (92\%); 3\% had ALAT levels above the normal range and $8 \%$ had abnormally low albumin levels. In $15 \%$ of specimens tested, total protein concentration was above the normal range and in 6\% it was below this. The widest variation was shown in the concentration of serum urea, only $56 \%$ (73/131) of observations lying within the normal range while $12 \%(16 / 131)$ were abnormally high, and $32 \%(42 / 131)$ were abnormally low. There was no statistically significant difference in the values for any test on comparison of those estimated before, during or after treatment. The number of estimations of serum concentration of 'sodium and potassium was few, but no alteration could be attributed to therapy with mecillinam. There was no association between high serum bilirubin concentration and therapy.

Haematological investigations were performed in forty-six babies. Haemoglobin concentration was below $13.5 \mathrm{~g} / 100 \mathrm{ml}$ in fourteen and in the same subjects the packed cell volume was below 0.44 , The values were not affected by mecillinam therapy nor was there any adverse effect on total or differential white cell counts.

One hundred and twenty one senum samples from 59 infants were assayed for mecillinam at random time intervals after a standard intramuscular dose and the results analysed.

There was wide variation in the serum levels achieved at any given time after mecillinam administration. Fig. 1 is a computer plotted regression line based on the data. Peak serum levels occurred within 15 minutes of intramuscular injection, a finding confirmed by subsequent investigation, and six hours after injection the serum level was $4-8 \mathrm{mg} / 1$. The individual results for all babies were combined and analysed by multiple regression analysis [1] with respect to birthweight, gestational age, relationship to the 10th centile and neo-

Tab. IV. Biochemical results on 66 neonates treated with mecillinam

\begin{tabular}{|c|c|c|c|c|}
\hline Test and range & & $\begin{array}{l}\text { Pre-treatment } \\
\text { Number and \% of } \\
\text { observations }\end{array}$ & $\begin{array}{l}\text { During treatment } \\
\text { Number and \% of } \\
\text { observations }\end{array}$ & $\begin{array}{l}\text { Post treatment } \\
\text { Number and } \% \text { of } \\
\text { observations }\end{array}$ \\
\hline $\begin{array}{l}\text { Blood Serum Urea } \\
(2.9-10.0 \mathrm{mmol} / \mathrm{l})\end{array}$ & $\begin{array}{l}\text { High } \\
\text { Normal } \\
\text { Low }\end{array}$ & $\begin{array}{r}4 / 9 \% \\
31 / 67 \% \\
11 / 24 \%\end{array}$ & $\begin{array}{r}9 / 21 \% \\
22 / 52 \% \\
11 / 26 \%\end{array}$ & $\begin{array}{l}3 / 7 \% \\
20 / 47 \% \\
20 / 47 \%\end{array}$ \\
\hline $\begin{array}{l}\text { Alanine amino transferase } \\
(2-27 \mathrm{iu} / 1)\end{array}$ & $\begin{array}{l}\text { High } \\
\text { Normal }\end{array}$ & $\begin{array}{r}3 / 6 \% \\
47 / 94 \%\end{array}$ & $\begin{array}{r}4 / 10 \% \\
38 / 90 \%\end{array}$ & $\begin{array}{r}2 / 5 \% \\
40 / 9.5 \%\end{array}$ \\
\hline $\begin{array}{l}\text { Total Protein } \\
(46-70 \mathrm{~g} / 1)\end{array}$ & $\begin{array}{l}\text { High } \\
\text { Normal } \\
\text { Low }\end{array}$ & $\begin{array}{r}8 / 17 \% \\
33 / 70 \% \\
6 / 13 \%\end{array}$ & $\begin{array}{r}6 / 16 \% \\
30 / 81 \% \\
1 / 3 \%\end{array}$ & $\begin{array}{r}5 / 12 \% \\
34 / 8.5 \% \\
1 / 3 \%\end{array}$ \\
\hline $\begin{array}{l}\text { Serum Albumin } \\
(29-55 \mathrm{~g} / 1)\end{array}$ & $\begin{array}{l}\text { High } \\
\text { Normal } \\
\text { Low }\end{array}$ & $\begin{array}{l}0 \\
40 / 91 \% \\
4 / 9 \%\end{array}$ & $\begin{array}{l}0 \\
32 / 91 \% \\
3 / 9 \%\end{array}$ & $\begin{array}{l}0 \\
34 / 94 \% \\
2,6 \%\end{array}$ \\
\hline
\end{tabular}

Normal values in parentheses 


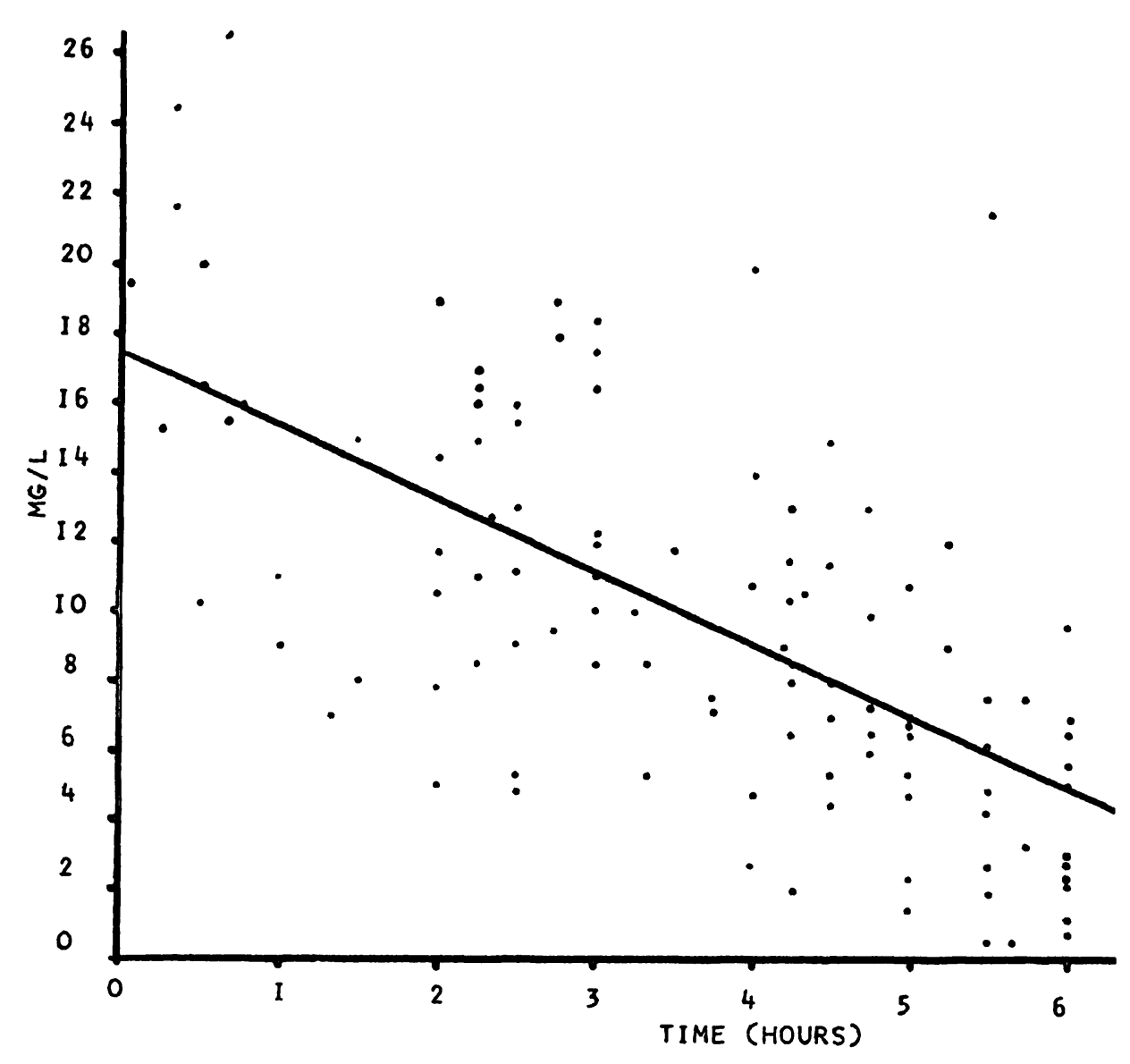

Fig. 1. Computer plotted regression line of cumulative mecillinam serum levels from 59 neonates after intramuscular injection.

natal age when treatment commenced. These cumulative results suggested that infants above the 10th centile born at less than 31 weeks gestation had a lower peak serum level and longer half life than those of more than 34 weeks gestation ( $p$ for the slope $<0.05)$. This difference was not associated with birthweight. Infants below the 10th centile for birthweight, head circumference or length had lower serum levels if treatment was started after the fourth neonatal day than similar infants treated before this time $(p<0.002)$ or infants above the 10th centile irrespective of neonatal age. The trough levels of mecillinam were the same for each of these groups. The cumulative half life for the 59 neonates studied was between 3 and 4 hours. Among infants born at less than 31 weeks gestation the half life was slightly longer. The reported half life in adults is $0.8 \mathrm{hr}$. [8].

\section{Discussion}

Pryse-Davies and Hurley [11] showed that infection was a primary cause of death in the perinatal period in 3.4 per cent of autopsies and a contributory cause in up to 20 per cent. Predominant amongst the microbes isolated was $\mathrm{E}$. coli, often resistant to ampicillin, and further analysis of their data shows that its incidence, relative to that of other microbes, increased over the ten year period of their study. There is, therefore, a good a priori case for inclusion in the therapeutic armamentarium of antibiotics active against $E$. coli and other Gram-negative rods encountered in neonatal practice. It is important that such agents should be entirely safe, for treatment of the newborn is often based on presumptive diagnosis [4] and, no doubt, many are treated unnecessarily [2]. 
The majority of systemic neonatal infections in our unit, in the United Kingdom, are caused by aerobic enteric Gram-negative rods (coliforms) or Streptococcus agalactiae (LANEFIELD group B streptococcus). Suspicion of serious infectious disease arises in about one third of babies on our intensive care unit, and, over the period of study described in this paper, systemic antibiotics were administered to seventy of 260 babies on the unit on suspicion of serious sepsis. Previously, these babies would have received ampicillin and flucloxacillin, or a penicillin and gentamicin, depending on the gravity of their clinical condition. All seventy received courses of mecillinam and penicillin. For ethical reasons, gentamicin was substituted for mecillinam in six.

Of nine babies with positive blood cultures at the time of the trial, six were treated successfully with full courses of mecillinam and penicillin; treatment in the other three was changed to gentamicin and penicillin: Two of the latter died. Thus, in appropriately chosen cases, mecillinam seems at least as effective as gentamicin in the treatment of serious infectious disease in the newborn.

Mecillinam had no deleterious effect on liver or renal function, as judged by measurement of serum ALAT, total protein, albumin or urea in sixty-six of the recipients, and of serum potassium, sodium and bilirubin in some. There was no ad- verse effect on the haemoglobin concentration nor on the white blood cell count. No rashes, gastrointestinal upsets or other 'signs of drug toxicity were noted, and resistance to the drug did not emerge during treatment. The number of mecillinam resistant isolates was no higher after the trial than before.

The wide variation in serum levels of mecillinam following a $10 \mathrm{mg} / \mathrm{Kg}$ intramuscular injection is consistent with reports for other antibiotics when used in this age group. The observation that in neonates the half life is longer (3-4 hours) than that reported in adults ( 0.8 hour) is not unexpected and the observation that the half life is longer than 4 hours in neonates of less than 31 weeks gestation is compatible with the renal immaturity of these infants. More detailed analysis of our findings would be unjustified because the data is cumulative.

Following this study the combination of mecillinam and penicillin by intramuscular injection has been used routinely in our Special Care Baby Unit for suspect or proven serious infections for fourteen months during which time it has proved safe and effective.

We regard mecillinam as a useful alternative to the less safe gentamicin in cases where the latter drug is not definitely indicated.

\section{Summary}

In an attempt to find a safe alternative to gentamicin as first line therapy the amidinopenicillin, mecillinam (Selexidin - LEO LABORATORIES) was used to treat 70 neonates with suspected or proven infection. These patients had a mean gestational age of $34.5 \pm 4.9$ weeks and a mean birthweight of less than $2.5 \mathrm{~kg}$. All the babies studied had complications of birth or early neonatal life which are known to predispose to potentially lethal infection. The treatment regimen consisted of intramuscular mecillinam (40 mg/Kg/day) and penicillin (60 000 unit/ $\mathrm{Kg} /$ day) divided into six hourly doses and administered separately for five days. Prior to the study these neonates would have received gentamicin and penicillin or ampicillin and cloxacillin.

Pathogenic or potentially pathogenic bacteria were isolated from 19 (29\%) infants (Tab. I). Prior to starting treatment $74 \%$ of isolates were sensitive to mecillinam or penicillin. The majority of resistant organisms were staphylococci (Tab. II). None of the babies had meningitis but blood cultures from 9 were positive. Eight of the
70 neonates died; but only one of the deaths was associated with infection and this occurred 4 months after discharge from hospital. No alteration in the sensitivity of appropriate bacteria to mecillinam was noted during the course of the study nor did the incidence of resistant bacteria in the unit change after the introduction of mecillinam. Estimations of serum alanine aminotransferase, total protein, albumin and urea were performed on 66 babies before, during and after mecillinam therapy. No significant differences were observed (Tab. IV). Mecillinam therapy did not affect the haemoglobin concentration, total or differential white cell count or serum sodium or potassium levels. No adverse clinical side effects were observed.

One hundred and twenty-one samples of serum from 59 neonates were assayed for mecillinam at varying times after injection and the results analysed.

There was wide variation in peak serum level (mean $17 \mathrm{mg} / \mathrm{l}$ ) and persistence of the drug. Peak serum levels occurred approximately. 15 minutes after intramuscular 
injection and six hours after injection the mean serum level was 4-8 mg/l. The serum half life was between 3 and 4 hours depending on gestational age. Multiple regression analysis of the assay results suggested that in infants of $<31$ weeks gestation the peak serum levels were lower and the half lifes longer than in those born at more than 34 weeks gestation ( $P$ for the slope $<0.05$ ). This difference was not associated with birthweight. The serum level was lower in infants below the 10th centile for birthweight, head circumference or length if treatment was started after the fourth neonatal day compared with similar babies treated before this time $(P<0.002)$ or neonates above the 10 th centile.

Evaluation of mecillinam in the treatment of suspected or proven infections in neonates has shown that it is a safe drug which is well tolerated and rapidly absorbed following intramuscular injection. Following the study the combination of mecillinam and penicillin has been used routinely as antibiotic treatment of first choice in our neonatal special care unit for fourteen months. We regard it as a useful alternative to gentamicin in cases were the use of an aminoglycoside is not definitively indicated.

Keywords: Bacterial infections, chemotherapy, infant, newborn, premature, low birthweight.

\section{Zusammenfassung}

\section{Mecillinam (Selexidin) in der Therapie bei Neugeborenen}

Ziel unserer Untersuchung war, eine sichere Alternative zum Gentamycin als Primärtherapie zu finden. Wir behandelten darum 70 Neugeborene mit Verdacht auf oder nachgewiesener Infektion mit Mecillinam (Selexidin LEO LABORATORIES). Die Kinder wurden bei einem durchschnittlichen Gestationsalter von $34.5 \pm 4.9$ Wochen geboren und hatten ein mittleres Geburtsgewicht von weniger als $2.5 \mathrm{~kg}$. Bei allen untersuchten Kindern waren Komplikationen während der Geburt oder in den ersten Lebenstagen aufgetreten, was als prädisponierender Faktor einer potentiell letalen Infektion angesehen werden muß. Die Medikation bestand aus einer Kombination von Mecillinam (40 mg/kg/d) und Penicillin (60 000 Einheiten/ $\mathrm{kg} / \mathrm{d}$ ); die Dosen wurden i.m. in sechsstündigem Abstand über 5 Tage jeweils separat verabreicht. Das bisherige Behandlungsschema bestand aus einer Kombination von Gentamycin and Penicillin oder Ampicillin und Cloxacillin.

Der Nachweis von pathogenen oder potentiell pathogenen Bakterien gelang bei 19 Kindern, d.e. 29\% (Tab. 1). Von den isolierten Keimen waren vor der Behandlung $74 \%$ gegenüber Mecillinam oder Penicillin empfindlich. Bei den resistenten Keimen handelte es sich überwiegend um Staphylokokken (Tab. II). Keines der Kinder hatte klinisch eine Meningitis, jedoch fanden sich bei 9 positive Blutkulturen. 8 der 70 Neugeborenen starben; nur bei einem ließ sich ein Zusammenhang mit einer Infektion herstellen. Das Kind starb 4 Monate nach der Entlassung aus dem Krankenhaus. Im Verlauf unserer Untersuchung änderte sich die Empfindlichkeit der primär sensitiven Keine gegenüber Mecillinam nicht. Auch die Zahl der resisten Keime blieb nach Therapiebeginn mit Mecillinam gleich.

Vor, während und nach der Mecillinamtherapie bestimmten wir GPT-, Gesamtprotein-, Albumin- und Harnstoffkonzentrationen. Es fanden sich keine signifikanten Un- terschiede (Tab. IV). Auch die Hb-Konzentration sowie die Leukozytenzahl oder auch das Differentialblutbild wurden durch die Therapie nicht beeinflußt, ebensowenig die $\mathrm{Na}^{+}$- und $\mathrm{K}^{+}$-Werte im Serum. Das klinische Bild entsprach diesen Befunden.

Bei 59 Neugeborenen wurden in definierten Zeitabständen nach der Injektion insgesamt 121 Blutproben entnommen und auf Mecillnam untersucht.

Es fand sich eine große Streubreite hinsichtlich der PeakKonzentrationen $(\bar{x}=17 \mathrm{mg} / \mathrm{l})$ und Halbwertszeiten. Die maximale Konzentration im Serum war etwa $15 \mathrm{~min}$ nach der intramuskulären Injektion erreicht, und $6 \mathrm{~h}$ nach der Injektion betrug die mittlere Serumkonzentration 4-8 mg/l. Die Halbwertszeit lag zwischen 3 und $4 \mathrm{~h}$ in Abhängigkeit vom Schwangerschaftsalter zum Zeitpunkt der Geburt. Die multiple Regressionsanalyse ergab, daß bei Kindern unterhalb der 31 . Woche die Peakkonzentrationen niedriger und die Halbwertszeiten länger waren als bei Kindern, die jenseits der 34. Schwangerschaftswoche geboren waren. Diese Unterschiede fanden sich unabhängig vom Geburtsgewicht. Auch lag der Serumspiegel niedriger bei Kindern unterhalb der 10er-Perzentile bezogen auf Geburtsgewicht, Kopfumfang und Länge -, wenn die Behandlung nach dem 4. Lebenstage begonnen wurde, gegenüber Kindern gleicher Reife, die schon früher behandelt wurden $(p<0.002)$ oder Neugeborenen oberhalb der 10er Perzentile.

Die Untersuchung zum Einsatz von Mecillinam bei Verdacht auf oder nachgewiesener Infektion bei Neugeborenen hat ergeben, daß es sich um ein sicheres, gut toleriertes und nach i.m.-Injektion schnell absorbiertes Pharmakon handelt. Nach dieser Studie wurde die Kombination von Mecillinam und Penicillin als antibiotische Therapie erster Wahl in unserer Neugeborenenstation über 14 Monate eingesetzt. Wir glauben, daß Mecillinam eine gute Alternative zum Gentamycin darstellt, und zwar in allen Fällen, wo Amino glycoside nicht eindeutig indiziert sind.

Schlïsselwörter: Bakterielle Infektionen, Chemotherapie, Frühgeborenes, geringes Geburt sgewicht, Kind, Neugeborenes. 


\section{Résumé}

Traitement des nouveaux-nés par le mecillinam (Selexidine)

Dans le but de trouver une alternative sûre de la gentamicine en tant que traitement de première intention, nous avons utilisé l'amidinopenicilline le mecillinam (Selexidin - LABORATOIRES LEO) dans le traitement de 70 infections néonatologiques prouvées ou suspectées. L'âge gestationnel moyen était de $34,5 \pm 4,9$ semaines et le poids de naissance moyen n'exédait pas $2500 \mathrm{~g}$. Tous ces nouveaux-nés montraient des complication natales ou néonatales précoces connues pour prédisposer à des infection potentiellement létales. La dose intramusculaire était de $40 \mathrm{mg} / \mathrm{kg} / \mathrm{jour}$ de mecillinam et de 60000 Unités/ $\mathrm{kg} /$ jour de pénicilline divisés en des doses appliquées toutes les 6 heures pendant 5 jours. Avant cette étude ces nouveaux-nés auraient reçu de la gentamicine et de la pénicilline ou bien de l'ampicilline et de la cloxacilline.

Des germes pathogènes ou potentiellement pathogènes ont été isolés chez 19 enfants (29\%) - (tableau 1). Avant d'instaurer le traitement $74 \%$ des germes isolés étaient sensibles à la mecilinam ou à la pénicilline. Ls majorité des organismes résistants étaient dẹ staphylo'coccoques (tableau 2). Aucun nouveau-né ne présentait une méningite mais les cultures de sang de 9 d'entre eux étaient positives. Huit des 70 nouveaux-nés moururent; mais seul un décés était lié à une infection et celà arriva 4 mois après la sortie de l'hôpital. La sensibilité des bactéries appropriées pour la mecillinam ne s'altéra pas au cours de l'étude; il n'y a pas eu d'incidence sur les germes résistants dans l'unité après l'introduction de la mecillinam. Nous avons dosés chez 66 nouveaux-nés avant, pendant et aprés le traitement à le mecillinam l'alamnine-aminotransférase sérique, les protéines totaux, l'albumine et l'urée. Nous n'avons point noté de differences significatives. (tableạu 4). Le traitement par la mecillinam n'affecte pas la concentration en hémoglobine, la numération globale ou la formule des globules blancs ni. les valeurs sériques de $\mathrm{K}$ et de Na. Nous n'avons pas noté des éffets secondaires cliniques.

Cent vingt et un échantillons de sérum de 59 nouveauxnés ont été dosés quant à la mecillinam après des temps variables suivant l'administration et les résultats ont été analysés.

Une large variabilité du pic sérique (moyenne $17 \mathrm{mg} / \mathrm{l}$ ) et de la persistance de la drogue ont été observées. Les pics étaient atteints environ 15 minutes après l'injection intramusculaire et 6 heures après l'injection les valeurs moyennes sériques attaignaient 4 à $8 \mathrm{mg} / \mathrm{l}$. La demi-vie sérique se situait entre 3 et 4 heures en fonction de l'age gravidique. Des analyses de régréssion multiples ont montré que chez les enfants de moins de 31 semaines le pic sérique était plus bas et les demi vies étaient plus longues par rapport à ceux des nés après la 34ème semaine (p inf. à 0.05). Cette différence n'est pas liée au poids de naissance. La valeur sérique était plus basse chez les enfants au dessous du 10 ème percentile de poids de naissance, de périmètre crânien ou de longueur si le traitement était débuté après le 4ème jour après la naissance, en comparaison avec des nouveaux-nés similaires traités avant ce délai ( $p$ inf à $0,0,02$ ) ou les nouveaux-nés au delà du 10 ème percentile.

Le mecillinam dans le traịtement d'infections prouvées ou suspectées des nouveaux-nés est une drogue sûre et bien tolerée ainsi que rapidement absorbée après administration intramusculaire. A la suite de cette étude nous avons utilisé la combinaison de mecillinam et de penicilline de façon systématique en tant que traitement de première intention dans notre unité périnatologique durant 14 mois. Nous le considérons comme une alternative utile de la gentamycine dans les cas où l'utilisation d'un aminoglycoside n'est pas définitivement indiquèe.

Mots-clés: Chimiothérapie, enfant, faible poids de naissance, infections bactériennes, nouveau-né, prémature.

Acknowledgement: We are grateful to Dr. DAVID HARVEY and Dr. ROBERT DINWIDDIE for allowing us to study their patients and to the medical and nursing staff of the Special Care Baby Unit for their help and support. Our gratitude is also due to Dr. ELIZABETH HUGHES and Mr. JOHN MEEK, Neonatal Biochemistry Unit, Hammersmith Hospital, London, who undertook the biochemical investigations and to Mrs. ANNE DOWMAN who carried out the statistical analysis. Mecillinam was kindly supplied by LEO LABORATORIES Limited.

\section{Bibliography}

[1] Programme Number P R p 393. Biomedical Computer P Series 1977: University of California Press, Los Angeles 1977

[2] Editorial: Neonatal bacteraemia: Diagnosis and management. Brit. Med. J. 4 (1979) 1385

[3] GODTFREDSEN, W. O.: An introduction to mecillinam. Antimicrobial Chemotherapy 3 (1977) (Suppl. B) 1
[4] GotofF, S. P., R. E. BEHRMANN: Neonatal septicaemia. Fetal Neonat. Med. 76 (1970) 142

[5] GRUNBERG, E., R. CLEELAND: In vivo activity of the $6 \beta$-amidinopenicillanic acid derivative, mecillinam, chemically linked or combined in varying ratios with 6 aminopenicillanic acid derivatives. Antimicrobial Chemotherapy 3 (1977) (Suppl. B) 59 
[6] LUND, F., K. ROHOLT, L. TYBRING, W. O. GODTFREDSEN: Mecillinam and pivmecillinam new $\beta$-lactam antibiotics with high activity against Gram-negative bacilli. In: WILliaMS, J. D., A. D. GEDDES (eds.): Chemotherapy. Vol. 5, Plessum Press, New York 1976

[7] LUND, F., F. TYBRING: $6 \beta$-amidinopenicillanic acids - A new group of antibiotics. Nature (London) New Biology 236 (1972) 135

[8] MITCHARD, M., J. ANDREWS, M. J. KENDALL, R. WISE: Mecillinam serum levels following intravenous injection: a comparison with pivmecillinam. Antimicrobial Chemotherapy 3 (1977) (Suppl. B) 83

[9] NEU, H. C.: Mecillinam, a novel penicillanic acid derivative with unusual activity against Gram-nega- tive bacteria. Antimicrobial Agents and Chemotherapy 9 (1976) 793

[10] NEU, H. C.: Mecillinam an amidinopenicillin which acts synergistically with other $\beta$-lactam compounds. Antimicrobial Chemotherapy 3 (1977) (Suppl. B) 43

[11] PRYSE-DAVIES, J., R. HURLEY: Infections and perinatal mortality. Antimicrobial Chemotherapy 5 (1979) (Suppl. A) 59

[12] REEVES, D. S.: Antibacterial activity of Mecillinam. Antimicrobial Chemotherapy 3 (1977) (Suppl. B) 5

[13] TYBRING, L., N. G. MELCHIOR: Mecillinam (FL 1060). A 6 6 -amidinopenicillanic acid derivative: bactericidal action and synergy in vitro. Antimicrobial Agents and Chemotherapy 8 (1975) 271

Received July 30, 1980. Accepted October 23, 1980.

Dr. J. de Louvois

Department of Microbiology

Queen Charlotte's Hospital for Women'

Goldhawk Road

London W6 OXG/England 